\title{
Peptide and Aptamer Decorated Delivery System for Targeting Delivery of Cas9/sgRNA Plasmid To Mediate Antitumor Genome Editing
}

Bo-Ya Liu, Xiao-Yan He, Chang Xu, Xiao-He Ren, Ren-Xi Zhuo and Si-Xue Cheng*

Key Laboratory of Biomedical Polymers of Ministry of Education, Department of

Chemistry, Wuhan University, Wuhan 430072, People's Republic of China

E-mail: chengsixue@whu.edu.cn. 


\section{Experimental details}

\section{Materials}

N-succinimidyl 3-(2-pyridyldithio) propionate (SPDP) was purchased from Sigma

Aldrich. Adipic dihydrazide (ADH), 1-hydroxybenzotriazole (HOBt), $\mathrm{N}$-(3-dimethylaminopropyl)-N'-ethylcarbodiimide hydrochloride (EDC) were supplied by Aladdin Industrial Corporation. Calcium chloride $\left(\mathrm{CaCl}_{2}\right)$, anhydrous sodium carbonate $\left(\mathrm{Na}_{2} \mathrm{CO}_{3}\right)$, and dimethyl sulfoxide (DMSO) were of analytical grade and were obtained from Sinopharm Chemical Reagent Co., Ltd. (Shanghai, China). 3-(4,5-Dimethylthiazol-2-yl)-2,5-diphenyltetrazolium bromide (MTT) and crystal violet were from Amresco. Hoechst 33342, YOYO-1 iodide and Lipofectamine 2000 were supplied by Invitrogen.

HeLa, HEK 293T, MCF-7 and H1299 cells were supplied by China Center for Typical Culture Collection (Wuhan, China), and cultured in Dulbecco's Modified Eagle's Medium (DMEM) supplemented with 10\% (v/v) fetal bovine serum (FBS), 2 $\mathrm{mg} \cdot \mathrm{mL}^{-1} \mathrm{NaHCO}_{3}$, and $100 \mathrm{U} / \mathrm{mL}$ antibiotics (penicillin-streptomycin).

\section{Characterization of plasmid loaded delivery systems}

To determine the assembly efficiency of Nalg, fluorescein labeled Nalg (Nalg-FITC) was used to prepare DS-ANalg. The nanoparticle containing solution was centrifuged at $4{ }^{\circ} \mathrm{C}$ for $1 \mathrm{~h}$ at $10000 \mathrm{rpm}$. After centrifugation, the amount of free Nalg remaining in the supernatant of solution was determined by spectrofluorometer $\left(\lambda_{\mathrm{ex}}, 495 \mathrm{~nm} ; \lambda_{\mathrm{em}}\right.$, $519 \mathrm{~nm})$. The assembly efficiency of Nalg was calculated as assembly efficiency $=\left(\mathrm{W}_{\mathrm{TN}}-\mathrm{W}_{\mathrm{FN}}\right) / \mathrm{W}_{\mathrm{TN}} \times 100 \%$ 
where $\mathrm{W}_{\mathrm{TN}}$ is the total weight of Nalg fed and $\mathrm{W}_{\mathrm{FN}}$ is the weight of non-assembled free Nalg.

The assembly efficiency of Nalg was determined to be $96.9 \%$.

After the preparation of DS-ANalg, the nanoparticle containing solution was centrifuged at $4{ }^{\circ} \mathrm{C}$ for $1 \mathrm{~h}$ at $10000 \mathrm{rpm}$. After centrifugation, the amount of free Aalg remaining in the supernatant of solution was quantified by Quant-iT ${ }^{\mathrm{TM}}$ OliGreen ${ }^{\circledR}$ ssDNA Reagent and Kit and then detected using a spectrofluorophotometer (RF-5301 PC, Shimadzu). The assembly efficiency of Aalg was calculated as

assembly efficiency $=\left(\mathrm{W}_{\mathrm{TA}}-\mathrm{W}_{\mathrm{FA}}\right) / \mathrm{W}_{\mathrm{TA}} \times 100 \%$, where $\mathrm{W}_{\mathrm{TA}}$ is the total weight of Aalg fed and $\mathrm{W}_{\mathrm{FA}}$ is the weight of non-assembled free Aalg.

The assembly efficiency of Aalg was determined to be $93.7 \%$.

The size and zeta potential of nanoparticles in deionized water were measured by a Zetasizer (Nano ZS, Malvern Instruments). Before measurements, $100 \mu \mathrm{L}$ of nanoparticle containing solution (containing $2 \mu \mathrm{g}$ of plasmid) was diluted to $1 \mathrm{~mL}$. Data were given as mean \pm standard deviation $(\mathrm{SD})$ based on 3 independent measurements.

To determine the encapsulation efficiency of plasmid, the delivery system containing solution was centrifuged at $4{ }^{\circ} \mathrm{C}$ for $1 \mathrm{~h}$ at $18000 \mathrm{rpm}$. After centrifugation, the amount of free plasmid remaining in the supernatant of solution was determined by the Quant-iT ${ }^{\mathrm{TM}}$ PicoGreen ${ }^{\circledR}$ dsDNA Assay Kit (Molecular Probes) according to the 
manufacturer's protocol using fluorescence spectroscopy (RF-5301 PC, Shimadzu). The plasmid encapsulation efficiency was calculated as encapsulation efficiency $=\left(\mathrm{W}_{\mathrm{TP}}-\mathrm{W}_{\mathrm{FP}}\right) / \mathrm{W}_{\mathrm{TP}} \times 100 \%$ where $\mathrm{W}_{\mathrm{TP}}$ is the total weight of plasmid fed and $\mathrm{W}_{\mathrm{FP}}$ is the weight of unencapsulated free plasmid.

The morphology of the multi-functional gene delivery system was visualized by transmission electron microscopy (TEM) (JEM-2100). The sample was stained with phosphotungstic acid aqueous solution.

\section{Cellular uptake study}

Plasmid FAK $(2 \mu \mathrm{g})$ was mixed with $5 \mu \mathrm{L}$ of YOYO-1 solution $(10 \mu \mathrm{M})$ and incubated for $15 \mathrm{~min}$ at $37{ }^{\circ} \mathrm{C}$ to obtain YOYO-1 labeled plasmid FAK. Cells were seeded in a $35 \mathrm{~mm}$ glass bottomed culture dish with the intensity of $5 \times 10^{4}$ cells/well and incubated at $37^{\circ} \mathrm{C}$ for $24 \mathrm{~h}$, and then the culture medium was removed. $1 \mathrm{~mL}$ of fresh medium containing YOYO-1 labeled plasmid FAK delivery system was added in the cells. The plasmid concentration for cell treatment was $2 \mu \mathrm{g} \cdot \mathrm{mL}^{-1}$. After co-incubation at $37^{\circ} \mathrm{C}$ for $4 \mathrm{~h}$, the cells were carefully washed three times by PBS. After the cells nuclei were stained by Hoechst 33342, the cells were observed by confocal laser scanning microscopy (CLSM) (PerkinElmer UltraVIEW VoX).

Intracellular fluorescence intensity of the cells incubated with the YOYO-1 labeled plasmid FAK delivery systems was determined by flow cytometry. After the cells were treated with YOYO-1 labeled plasmid FAK delivery systems $\left(2 \mu \mathrm{g} \cdot \mathrm{mL}^{-1}\right)$ for $4 \mathrm{~h}$, the cells were carefully washed with PBS. The cells were collected by centrifugation 
at $1500 \mathrm{rpm}$ for $3 \mathrm{~min}$, then washed twice with PBS, and re-suspended in PBS. Then the cells were filtered and examined by flow cytometry (BD FACS Aria III) using the FL1-H channel.

\section{Study on gene transfection}

Cells were seeded in a 24 -well plate with the intensity of $5 \times 10^{3}$ cells/well and incubated at $37^{\circ} \mathrm{C}$ for $24 \mathrm{~h}$. Then plasmid GFP loaded nanoparticles were added, and cells were co-incubated with plasmid GFP loaded nanoparticles with a plasmid concentration of $2 \mu \mathrm{g} \cdot \mathrm{mL}^{-1}$ at $37^{\circ} \mathrm{C}$ for $48 \mathrm{~h}$. Then the cells were carefully washed with PBS, and observed by a fluorescence microscope (Olympus IX73).

\section{Western blot analysis}

After being treated with plasmid delivery systems with a plasmid concentration of 2 $\mu \mathrm{g} \cdot \mathrm{mL}^{-1}$ at $37^{\circ} \mathrm{C}$ for $48 \mathrm{~h}$, the cells were collected and washing with PBS carefully. Then the cells were lysed and re-suspended in sodium dodecyl sulfate (SDS) sample buffer containing $1 \%$ b-mercaptoethanol. Total protein extracts were subjected to SDS-polyacrylamide gel electrophoresis (PAGE). After electrophoresis, the proteins were transferred to poly (vinylidene fluoride) (PVDF) membranes (Millipore). To block non-specific binding sites, the membranes were treated for $1 \mathrm{~h}$ with TBST (mixture of Tris-buffered saline and Tween-20) containing 5\% milk. Subsequently the membranes were incubated with the primary antibody overnight at $4^{\circ} \mathrm{C}$. After washing, the membranes were incubated with the secondary antibody for $1 \mathrm{~h}$.

To study the the release of cytochrome $\mathrm{C}$ (cyt-C), cyt-C in the mitochondria and cytosol was detected, separately. The cells were broken down by hypotonic solution 
and centrifuged at $12000 \mathrm{rpm}$ for $10 \mathrm{~min}$. The supernatant was collected for the detection of cyt-C in the cytosol. After the supernatant was completely removed, cyt-C in the mitochondria was extracted by a particular protein extract reagent. GAPDH and VDCA were used as housekeeping proteins for the cell cytosol and mitochondria, respectively.

\section{Real-time quantitative PCR}

Real-Time quantitative PCR was used to detect mRNA of FAK, mRNA of p53, and sgRNA for genome editing. After being treated by plasmid delivery systems with a plasmid concentration of $2 \mu \mathrm{g} \cdot \mathrm{mL}^{-1}$ at $37^{\circ} \mathrm{C}$ for $48 \mathrm{~h}$, HeLa cells were harvested and the total RNA was isolated from the cell lysates with a High Pure RNA Isolation Kit (Invitrogen). cDNA was synthesized and purified with PrimeScript RT Reagent Kit (Takara). The sequences of primers are as follows. Forward 5'-TACACCATGCCCTCAACCAG-3' and reverse 5'-TCAAACTGACGCATTGTTAAGG-3' for detection of mRNA of FAK. Forward 5`GCGCACAGAGGAAGAGAATCT-3`2 and reverse 5-TATGGCGGGAGGTAGACTGAC-3` for detection of mRNA of p53. Forward 5'-AAATTCAAAGTCTCAACTGAATTGC-3' and reverse 5'-CTCAACTGGTGTCGTGGAGTC-3' for detection of sgRNA. Real-time quantitative PCR was performed on StepOne Real-Time PCR system (Life Technologies), using SYBR Premix Ex Taq Kit (TaKaRa). The results were analyzed using the $2^{-\Delta \Delta \mathrm{ct}}$ method.

\section{Surveyor assay}


After HeLa cells were treated with plasmid FAK delivery systems with a plasmid concentration of $2 \mu \mathrm{g} \cdot \mathrm{mL}^{-1}$ at $37^{\circ} \mathrm{C}$ for $48 \mathrm{~h}$, the cells were harvested and genomic DNA was extracted using QuickExtract DNA extraction solution (Epicentre). Genomic regions were amplified by PCR. Homoduplex PCR products were denatured and rehybridized using stepdown annealing conditions to generate homo- and heteroduplexes. The mixture of duplexes was treated with Surveyor nuclease at $37{ }^{\circ} \mathrm{C}$ for $1 \mathrm{~h}$. The products were electrophoresed on a $2 \%$ agarose gel.

\section{Detection on mRNA of p53 during genome editing}

Co-delivery systems, MB@DS-ANalg and MB@*DS-ANalg, were prepared by a similar procedure as that of DS-ANalg and *DS-ANalg, during which 0.2 nmol of $\mathrm{MB}$ and $2 \mu \mathrm{g}$ of plasmid were added in the precursor solution.

HeLa cells $\left(5 \times 10^{4}\right.$ cells in $1 \mathrm{~mL}$ of medium) were seeded in a $35 \mathrm{~mm}$ glass bottomed culture dish and incubated at $37{ }^{\circ} \mathrm{C}$ for $24 \mathrm{~h}$. Then the culture medium was removed, and $1 \mathrm{~mL}$ of fresh medium containing MB@DS-ANalg or MB@*DS-ANalg was added. The plasmid concentration for cell treatment was $2 \mu \mathrm{g} \cdot \mathrm{mL}^{-1}$, and the MB concentration for cell treatment was $0.2 \mathrm{nmol} \mathrm{mL}^{-1}$. After incubation at $37^{\circ} \mathrm{C}$ for $48 \mathrm{~h}$, the cells were washed twice with ice cold PBS, and p53-triggered fluorescence was imaged by CLSM (PerkinElmer UltraVIEW VoX) under magnification of 400.

\section{Enzyme linked immunosorbent assay (ELISA)}


To study the immunogenicity of blank vectors, RAW264.7 cells were seeded on a 96-well culture plate at a density of $1 \times 10^{4}$ cells/well. After $24 \mathrm{~h}$ incubation at $37{ }^{\circ} \mathrm{C}$, the cells were rinsed with PBS, and the medium was replaced by $100 \mu \mathrm{L}$ of fresh culture medium containing blank nanoparticles without plasmid loading. The blank nanoparticles concentration was the same as that for genome editing. Then the cells were co-incubated with the blank nanoparticles at $37{ }^{\circ} \mathrm{C}$ for $48 \mathrm{~h}$. After that, the cell supernatant was collected after centrifugation at $1000 \mathrm{rpm}$ for $10 \mathrm{~min}$, and then stored at $-70{ }^{\circ} \mathrm{C}$ until use. The concentration of cytokines (IL-6 and TNF- $\alpha$ ) in the supernatant was determined by enzyme-linked immunosorbent assay (ELISA) kit (4A Biotech Co., Ltd.).

\section{Study on cell growth inhibition}

Cells were seeded in a 96-well plate with the intensity of $5 \times 10^{3}$ cells/well. After $24 \mathrm{~h}$ incubation, the cells were co-incubated with the plasmid delivery system with a plasmid concentration of $2 \mu \mathrm{g} \cdot \mathrm{mL}^{-1}$ at $37^{\circ} \mathrm{C}$ for $24 \mathrm{~h}$ or $48 \mathrm{~h}$. After that, MTT $(20 \mu \mathrm{L}$, $5 \mathrm{mg} \cdot \mathrm{mL}^{-1}$ ) was added to each well, followed by incubation at $37{ }^{\circ} \mathrm{C}$ for $4 \mathrm{~h}$. Then the supernatant was removed, and DMSO was added to dissolve the formazan crystals produced by viable cells. The absorbance of the solution was measured using a microplate reader (Bio-Rad 550) at $570 \mathrm{~nm}$ to determine the OD value. Data were given as mean \pm standard deviation (SD) based on 3 independent measurements.

\section{Apoptosis assay}

Annexin V labeled with fluorescein isothiocyanate (annexin V-FITC)/propidium iodide (PI) apoptosis detection kit (BD Biosciences) was used to determine apoptotic 
rate of HeLa cells. HeLa cells were seeded in 6-well plates at $1 \times 10^{5}$ cells/well and incubated for $24 \mathrm{~h}$. The medium was separately replaced by $2 \mathrm{~mL}$ of complete medium containing DS-ANalg or *DS-ANalg. After $48 \mathrm{~h}$ incubation at $37^{\circ} \mathrm{C}$ with a plasmid concentration of $2 \mu \mathrm{g} \cdot \mathrm{mL}^{-1}$, the cells were harvested and washed with PBS, and then the cells were centrifuged and resuspended in $300 \mu \mathrm{L}$ of binding buffer in the kit. Thereafter, cells were incubated with $5 \mu \mathrm{L}$ of annexin V-FITC for 10 min and $5 \mu \mathrm{L}$ of PI for $5 \mathrm{~min}$ in dark, respectively. The fluorescence intensity of cells was measured using a flow cytometer (BD FACS Aria III).

\section{Study on mitochondrial transmembrane potential ( $\Delta \Psi \mathrm{\Psi m})$ by JC-1 assay}

JC-1 Mitochondrial Membrane Potential Assay kit (Beyotime Institute of Biotechnology) was used to evaluate mitochondrial membrane potential $(\Delta \Psi \mathrm{m})$ of cells. Briefly, cells were incubated with the medium containing $\mathrm{JC}-1$ at $37^{\circ} \mathrm{C}$ for 20 min after cells were treated with DS-ANalg or *DS-ANalg at a plasmid concentration of $2 \mu \mathrm{g} \cdot \mathrm{mL}^{-1}$ at $37^{\circ} \mathrm{C}$ for $48 \mathrm{~h}$. After washing with ice-cold JC-1 staining buffer for two times, the cells were observed by confocal laser scanning microscopy (CLSM) (PerkinElmer UltraVIEW VoX). Additionally, cells were collected and rinsed with PBS, and then analyzed using a flow cytometer (BD FACS Aria III). The ratio of red fluorescence intensity to green fluorescence intensity representes the $\Delta \Psi \mathrm{m}$ level.

\section{Wound healing assay}

HeLa cells were treated with DS-ANalg or *DS-ANalg with a plasmid concentration of $2 \mu \mathrm{g} \cdot \mathrm{mL}^{-1}$ at $37^{\circ} \mathrm{C}$ for $48 \mathrm{~h}$, and then the medium was removed. The cells were carefully washed with PBS, and then seeded in 6-well culture plates at a density of $5 \times 10^{4}$ cells/well. After growing to $90 \%$ confluence, a linear scratch was created in the 
monolayer of cells with a sterile $200 \mu \mathrm{L}$ micropipette tip, and the detached cells were removed by rinsing with PBS for three times. The remained cells were incubated with DMEM containing 2\% FBS. The cells migrating to the wounded region after $24 \mathrm{~h}$ incubation were observed by an inverted microscope (Olympus, IX73). Images were analyzed using ImageJ software.

\section{Transwell assay}

Matrigel (BD Biosciences) was diluted with serum-free medium at the ratio of 1:8. After that, the upper chamber of transwell was coated with diluted Matrigel $(100 \mu \mathrm{L}$ per well) and then placed into a 24 -well bottom chamber, and incubated at $37^{\circ} \mathrm{C}$ for $30 \mathrm{~min}$ in a $5 \% \mathrm{CO}_{2}$ incubator. HeLa cells were treated with DS-ANalg or *DS-ANalg with a plasmid concentration of $2 \mu \mathrm{g} \cdot \mathrm{mL}^{-1}$ at $37^{\circ} \mathrm{C}$ for $48 \mathrm{~h}$, and then the medium was removed. The cells were carefully washed with PBS, and then seeded in the Matrigel coated upper chamber $\left(1 \times 10^{4}\right.$ cells/well $)$ and incubated in serum-free DMEM. The lower chamber was filled with DMEM containing 10\% FBS. After incubation for $24 \mathrm{~h}$, the noninvasive cells remaining on the upper chambers were removed by cotton swabs, and the invaded cells on the lower surface of the filter were fixed and stained by methyl alcohol and $0.1 \%$ crystal violet. Then the invaded cells were observed by an inverted microscope (Olympus, IX73). 
Table S1. Size, zeta potential and encapsulation efficiency of plasmid delivery systems.

\begin{tabular}{|c|c|c|c|c|c|}
\hline \multirow{3}{*}{ Sample ID } & \multirow{3}{*}{ Composition } & \multirow{3}{*}{ Size (nm) } & \multirow{3}{*}{ PDI } & \multirow{2}{*}{$\begin{array}{l}\text { Zeta } \\
\text { potential }\end{array}$} & \multirow{3}{*}{$\begin{array}{l}\text { Encapsulation } \\
\text { efficiency }(\%)\end{array}$} \\
\hline & & & & & \\
\hline & & & & $(\mathrm{mV})$ & \\
\hline DS-alg & plasmidFAK@PS/CaCO $3 /$ alg & $205 \pm 5$ & 0.26 & $-11.9 \pm 0.3$ & 97.2 \\
\hline DS-Nalg & plasmid FAK@PS/CaCO $3 / \mathrm{Nalg} / \mathrm{alg}$ & $218 \pm 8$ & 0.19 & $-8.3 \pm 0.2$ & 92.9 \\
\hline DS-Aalg & plasmid FAK@PS/CaCO 3 /Aalg/alg & $226 \pm 5$ & 0.16 & $-12.2 \pm 0.4$ & 97.6 \\
\hline DS-ANalg & plasmid FAK@PS/CaCO $3 /$ Aalg/Nalg & $249 \pm 6$ & 0.12 & $-10.8 \pm 0.1$ & 93.7 \\
\hline$*$ DS-alg & plasmid NC@PS/CaCO $3 /$ alg & $208 \pm 3$ & 0.25 & $-11.3 \pm 0.4$ & 96.0 \\
\hline *DS-Nalg & plasmid NC@PS/CaCO $3 / \mathrm{Nalg} / \mathrm{alg}$ & $221 \pm 4$ & 0.14 & $-8.1 \pm 0.1$ & 94.2 \\
\hline *DS-Aalg & 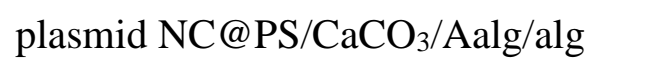 & $232 \pm 6$ & 0.13 & $-11.5 \pm 0.5$ & 96.7 \\
\hline$*$ DS-ANalg & plasmid NC@PS/CaCO $3 / \mathrm{Aalg} / \mathrm{Nalg}$ & $250 \pm 4$ & 0.15 & $-10.6 \pm 0.4$ & 95.7 \\
\hline
\end{tabular}


Table S2. The concentration of IL-6 and TNF- $\alpha$ in the cell supernatant of RAW264.7 cells treated with blank delivery vectors for $48 \mathrm{~h}$. The cells without treatment were used as a control.

\begin{tabular}{lll}
\hline Treatment & $\mathrm{IL}-6\left(\mathrm{pg} \mathrm{mL}{ }^{-1}\right)$ & $\mathrm{TNF}-\alpha\left(\mathrm{pg} \mathrm{mL}{ }^{-1}\right)$ \\
\hline Control & $97.2 \pm 5.7$ & $481.2 \pm 3.4$ \\
$\mathrm{PS} / \mathrm{CaCO}_{3} / \mathrm{alg}$ & $100.4 \pm 6.2$ & $476.3 \pm 6.1$ \\
$\mathrm{PS} / \mathrm{CaCO}_{3} / \mathrm{Nalg} / \mathrm{alg}$ & $89.9 \pm 9.1$ & $497.2 \pm 7.7$ \\
$\mathrm{PS} / \mathrm{CaCO}_{3} / \mathrm{Aalg} / \mathrm{alg}$ & $96.6 \pm 2.2$ & $491.7 \pm 9.0$ \\
$\mathrm{PS} / \mathrm{CaCO}_{3} / \mathrm{Aalg} / \mathrm{Nalg}$ & $101.3 \pm 8.1$ & $470.4 \pm 8.5$ \\
\hline
\end{tabular}


a

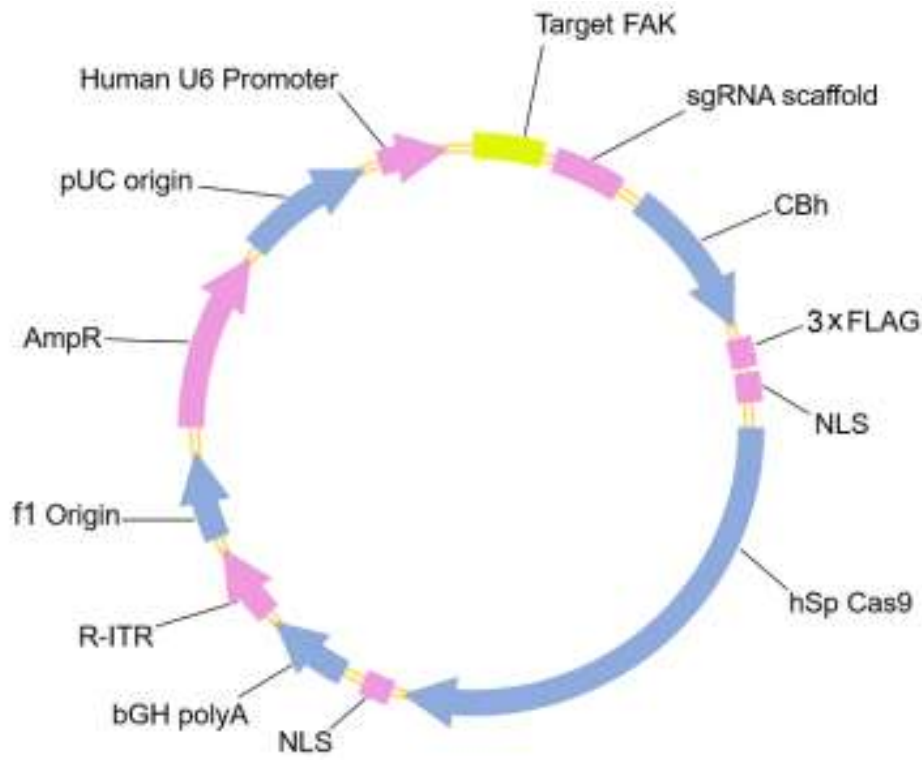

TGATIACCAGGCTGITAGAGAGATAATTGGAATTAATITGACTGTAAACA CAAAGATATTAGTACAAAATACGTGACGTAGAAAGTAATAATTTCTTGGG TAGTITGCAGTTITAAAATIATGIITAAAATGGACTATCATATGCTTACC GTAACTTGAAAGTATTTCGATITCTIGGCTITATATATCTTGTGGAAAGGA CGAAACACCGIGATAGAAGAANTTCAAAGTOTITTAGAGCTAGAMATAGC AAGTTAAAATAAGGCTAGTCCGTTATCAACTTGAAAAAGTGGCACCGAGT CGGTGCTTTTTTGTTTTAGAGCTAGAAATAGCAAGTTAAAATAAGGCTAGT COGTITTAGCGCGTGCGCCAATTCTGCAGACAAATGGCTCTAGAGGTAC COGTTACATAACTTACGGTAAATGGCCOGCCTGGCTGACCGCCCAACGAC OCCCGCOCATTGACGTCAATAGTAACGCCAATAGGGACTTTCCATTGACG TCAATGGGTGGAGTATITACGGTAAACTGCCCACTTGGCAGTACATCAAG TGTATCATATGCCAAGTACGCCCCCTATTGACGTCAATGACGGTAAATGG COCGCCTGGCATTGTGCCCAGTACATGACCTIATGGGACTTICCTACTTOG CAGTACATCTACGTATTAGTCAAC

b

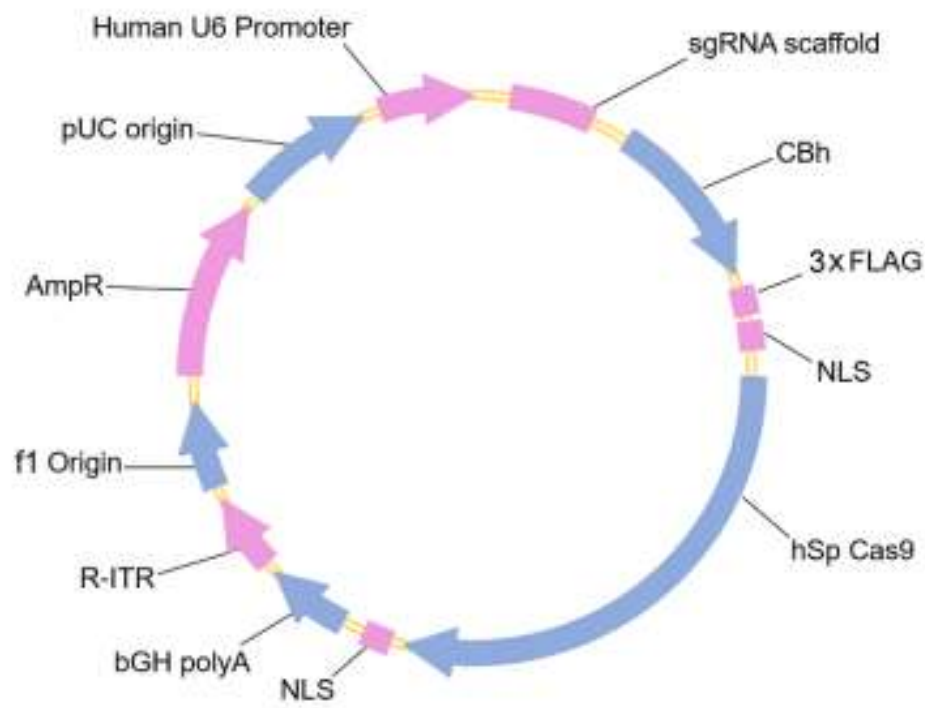

Figure S1. The structure of (a) plasmid FAK and (b) plasmid NC. 


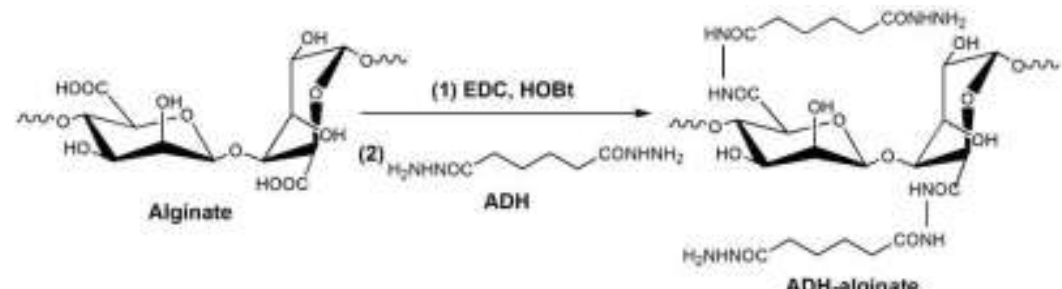

ADH-alginate
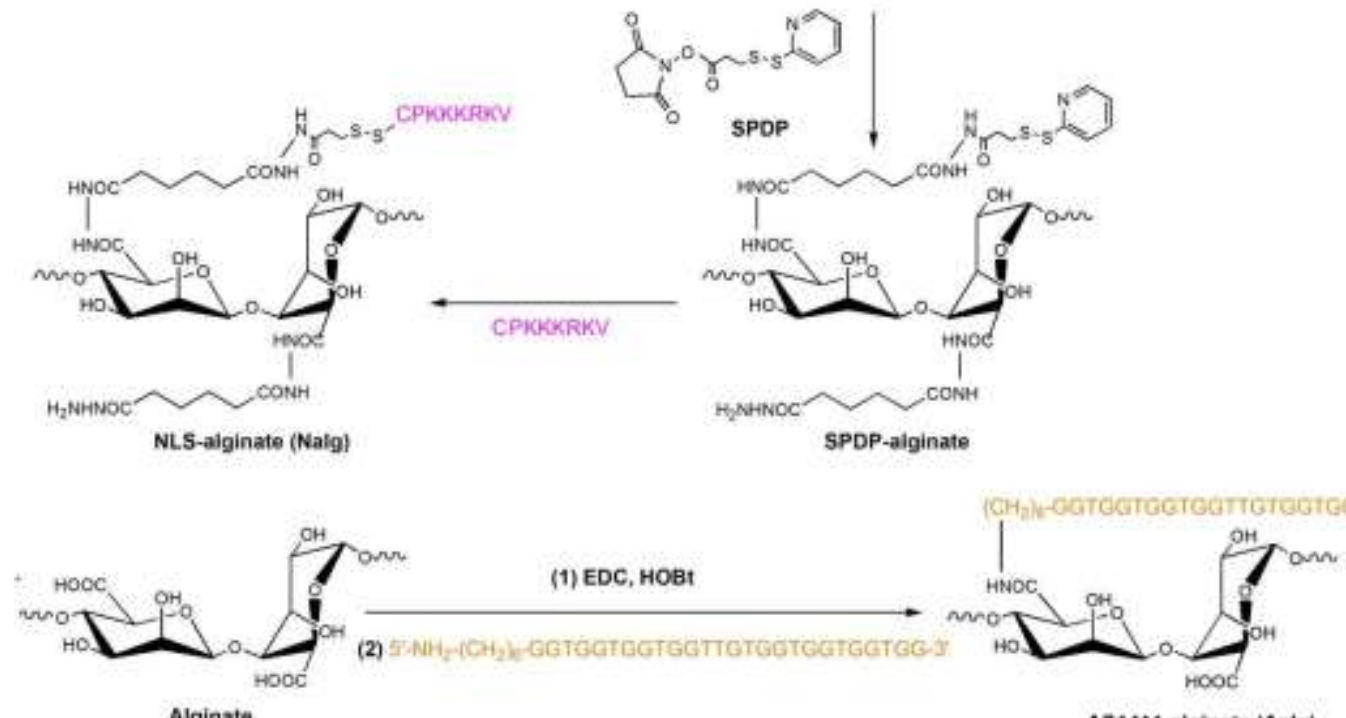

A51411-alginate (Aalg)

Figure S2. Synthesis of NLS peptide conjugated alginate (Nalg) and AS1411 conjugated alginate (Aalg). 

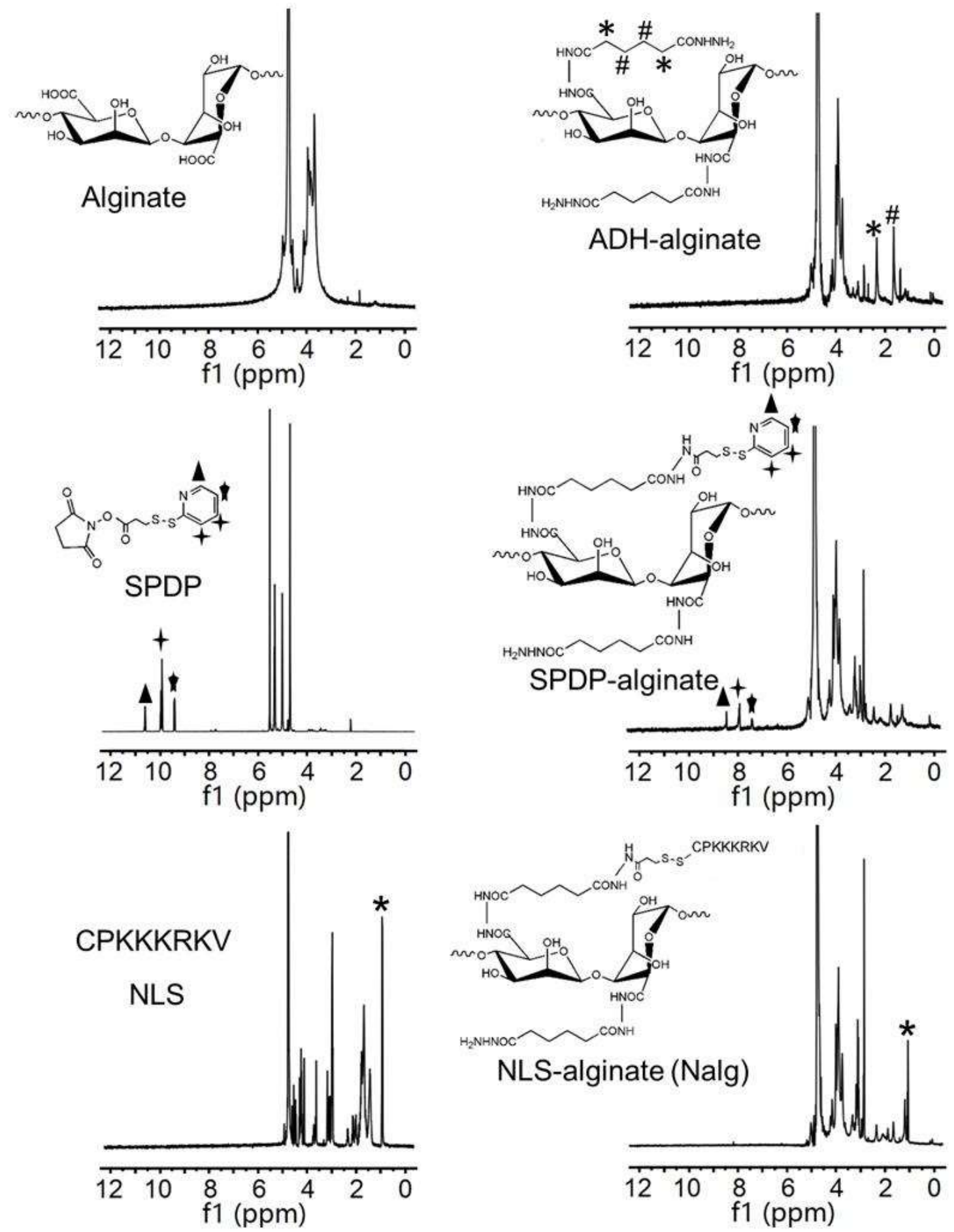

Figure S3. ${ }^{1} \mathrm{H}$ NMR spectra of alginate in $\mathrm{D}_{2} \mathrm{O}$, SPDP in DMSO-D $_{6}$, NLS peptide in $\mathrm{D}_{2} \mathrm{O}, \mathrm{ADH}$-alginate in $\mathrm{D}_{2} \mathrm{O}, \mathrm{SPDP}$-alginate in $\mathrm{D}_{2} \mathrm{O}$, and Nalg in $\mathrm{D}_{2} \mathrm{O}$. 

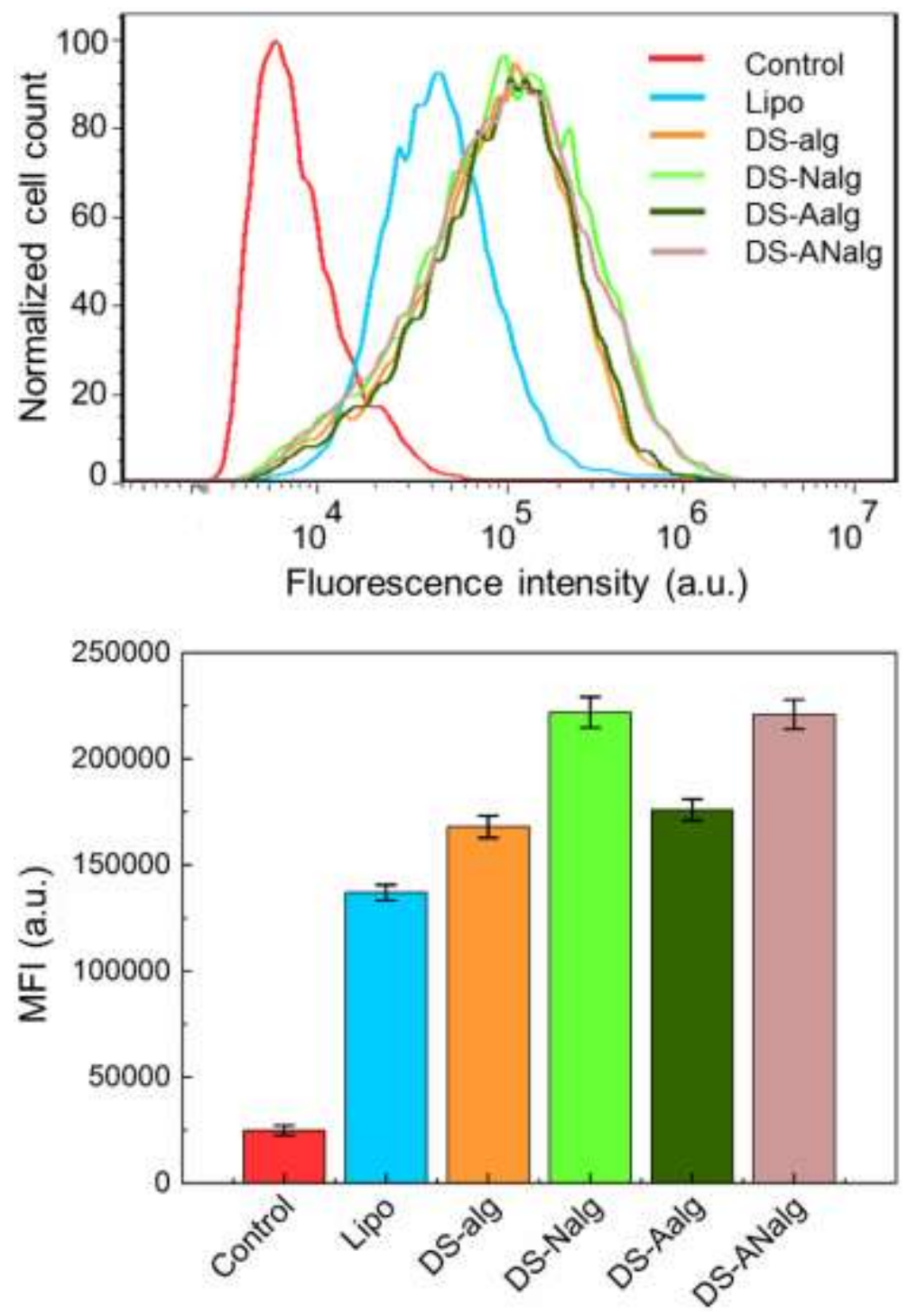

Figure S4. Flow cytometry analysis on cellular uptake of YOYO-1 labeled plasmid FAK in HEK 293T cells after co-incubation with plasmid delivery systems for $4 \mathrm{~h}$. 

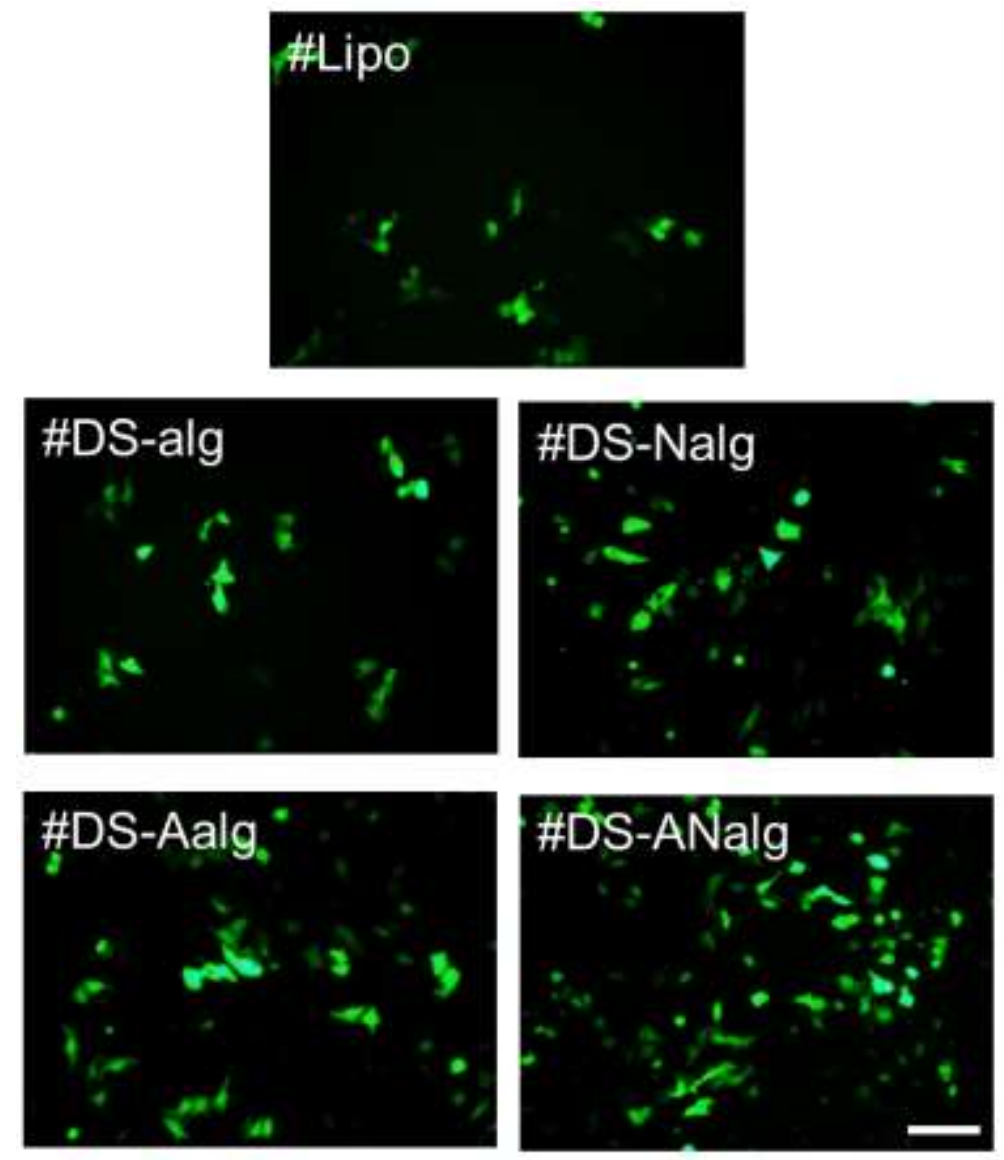

Figure S5. Expression of GFP mediated by different delivery vectors in HeLa cells observed by fluorescence microscopy under the magnification of 400 . The cells were treated by delivery systems for $48 \mathrm{~h}$. Scale bar: $100 \mu \mathrm{m}$. 

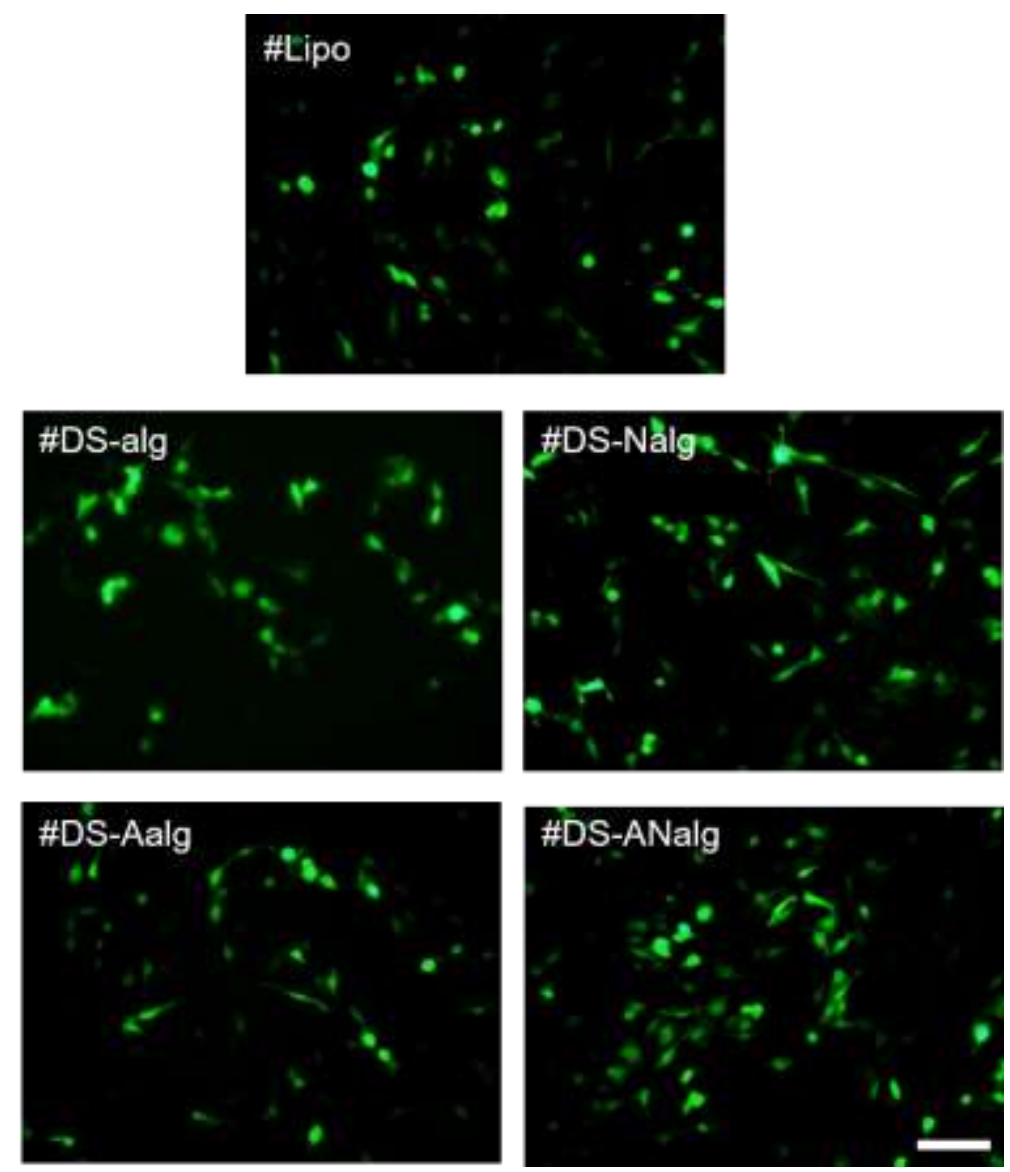

Figure S6. Expression of GFP mediated by different delivery vectors in HEK 293T cells observed by fluorescence microscopy under the magnification of 400 . The cells were treated by delivery systems for $48 \mathrm{~h}$. Scale bar: $100 \mu \mathrm{m}$. 


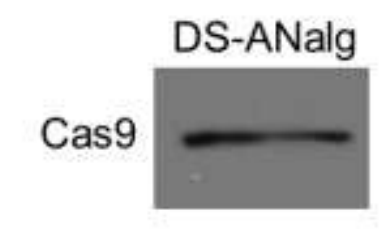

GAPDH
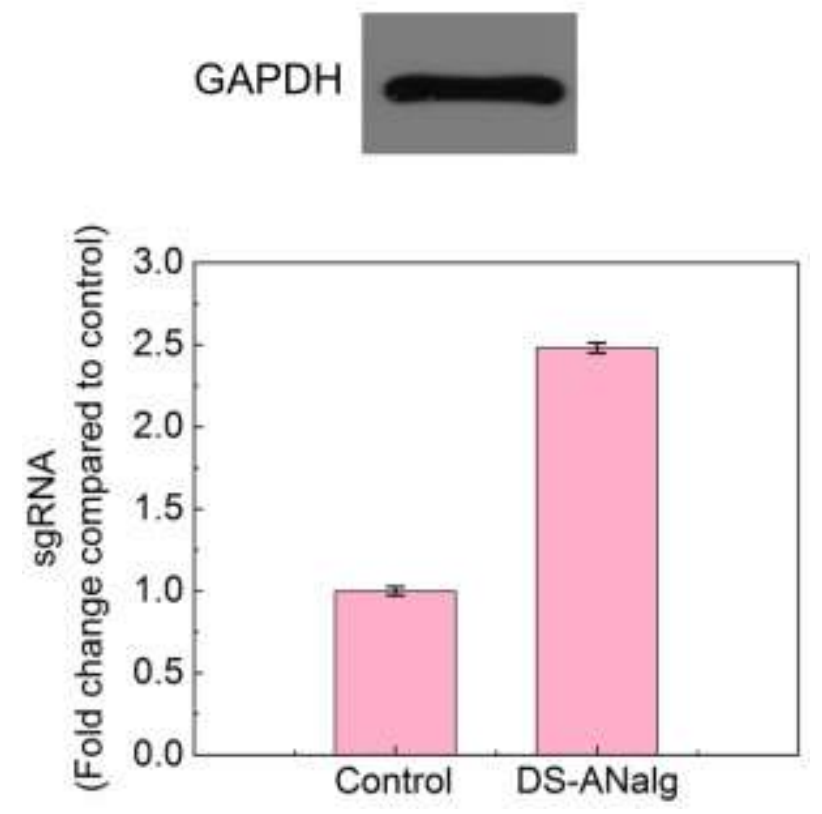

Figure S7. Expression of Cas9 protein determinded by Western blot analysis, and PCR analysis on sgRNA. HeLa cells were treated by DS-ANalg for $48 \mathrm{~h}$. Untreated cells were used as a control.

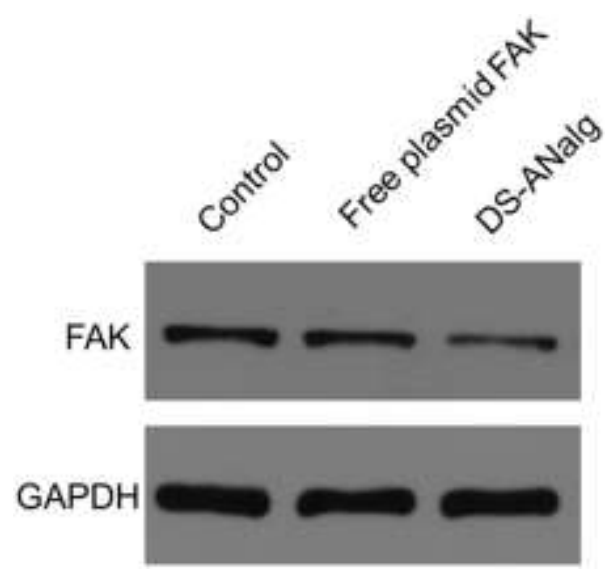

Figure S8. FAK expression in HeLa cells after being treated by free plasmid FAK and DS-ANalg for $48 \mathrm{~h}$. Untreated cells were used as a control. 

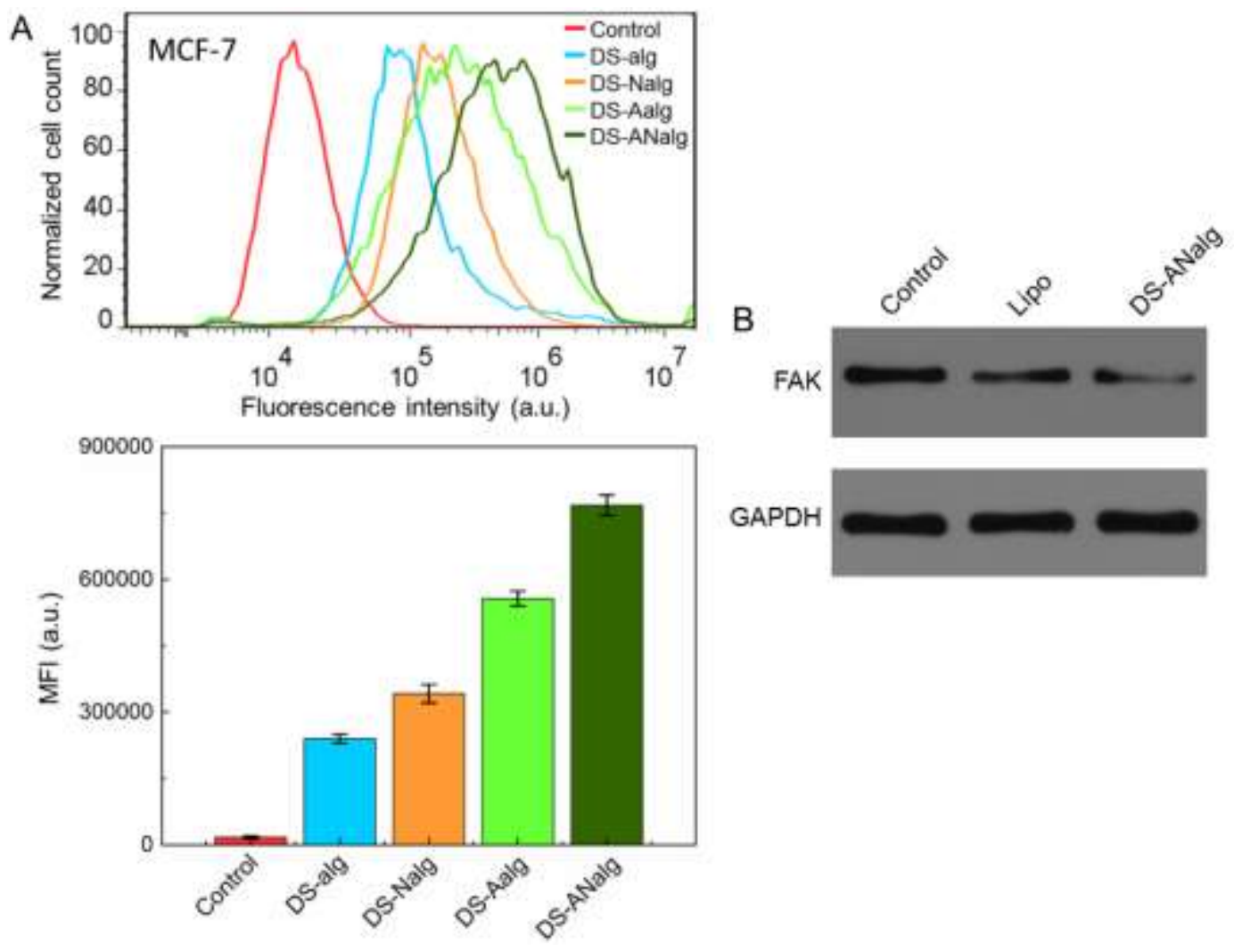

Figure S9. (A) Flow cytometry analysis on cell uptake of YOYO-1 labeled plasmid

FAK in MCF-7 cells after co-incubation with plasmid delivery systems for 4 h. (B)

Western blot analysis on FAK knockout in tumorous MCF-7 cells after genome editing by plasmid FAK delivery systems for $48 \mathrm{~h}$. 

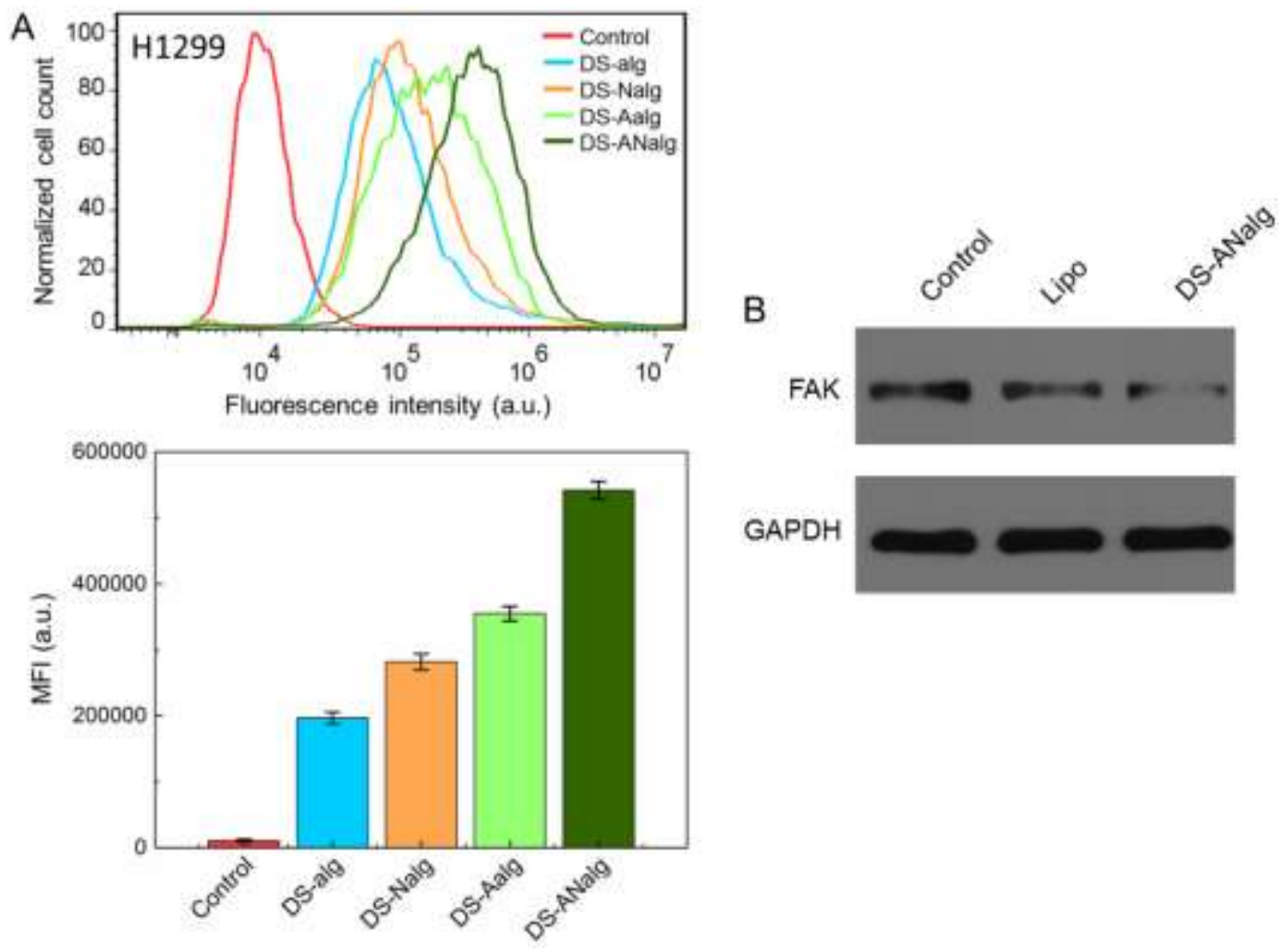

Figure S10. (A) Flow cytometry analysis on cell uptake of YOYO-1 labeled plasmid FAK in H1299 cells after co-incubation with plasmid delivery systems for 4 h. (B) Western blot analysis on FAK knockout in tumorous H1299 cells after genome editing by plasmid FAK delivery systems for $48 \mathrm{~h}$. 